\title{
Implementation of the Zakat Village Index to Support a Zakat Community Development Program in Bedono Village, Demak District
}

\author{
Farikhatusholikhah, Tanti Novianti, and Khalifah Muhamad Ali \\ Bogor Agricultural University
}

\begin{abstract}
BAZNAS is the organization that manages zakat on a national level, working toward alleviating poverty in Indonesia through its Zakat Community Development (ZCD) program. The ZCD program focuses on community-based development through the empowerment of the mustahik community living in rural areas. This study aims to measure the level of welfare and determine the eligibility of Bedono Village, Demak District to receive assistance in the form of zakat funds through the ZCD program. This research employed a survey method using interviews and focus group discussion, combined with a questionnaire. The analytical tool used in this analysis is the Multi-Stage Weighted Index. This research reveals the condition of Bedono Village to be "fairly good," with an index score of 0.49. This means that Bedono Village can be considered for eligibility to receive help in the form of zakat.
\end{abstract}

Keywords: Zakat Community Development (ZCD) program, Zakat Village Index (ZVI)

\section{INTRODUCTION}

Bedono Village in Sayung Subdistrict, Demak Regency experiences the most severe impacts of tidal flooding compared to other areas in Demak Regency (Damaywanti, 2013). The village covers an area of 739.20 ha, with 331.31 ha of yard and pond areas that become submerged in the event of a flood (Sayung Subdistrict in Figures or Kecamatan Sayung dalam Angka 2017). Bedono Village formerly comprised seven hamlets (Dusun in Indonesian), namely Morosari, Tambaksari, Pandansari, Tonosari, Rejosari Senik, Bedono, and Mondoliko. Since 2004, however, only five hamlets have remained. Tambaksari and Rejosari Senik were relocated to Sidogemah and Purwosari Villages in 2004 due to the increasingly severe erosion, which had led to them being permanently flooded with sea water (Damaywanti 2013).

Zakat, as one of the tools for distributing assets in Islam, is considered to provide a means of reducing the problems of inequality and poverty. Based on data for the management of zakat provided by The National Board of Zakat (BAZNAS, or Badan Amil Zakat Nasional) Demak Regency (2018), a total of 3,332,125,197 rupiahs in zakat funds was collected in 2017, which was an increase of 46.49 percent from 2016.

BAZNAS, as the organization that manages zakat nationally, contributes to resolving the problems of poverty and the gaps that occur in Indonesia. One of the ways in which it does this is via the implementation of the Zakat Community Development (ZCD) program. The ZCD program aims to empower communities by targeting those groups of mustahik who live in villages but who have tended to be left behind in terms of prosperity, facilities, and infrastructure. The allocation of productive-based zakat to the village community aims to help the mustahik community work together to utilize the managed funds, with the goal of raising 
their prosperity not only in material terms but also in the areas of education, health, and spiritual well-being.

The Zakat Village Index (ZVI, or Indeks Desa Zakat) is considered to be a benchmark in assessing and evaluating the process of empowerment programs for rural communities. The ZVI comprises the following five dimensions: Economic, Health, Education, Social Humanity, and Da'wah. Each dimension consists of 15 variables and 39 indicators with their own contribution weightings. By calculating the ZVI value/score of a village, we can reveal the status of that village in terms of its potential to receive zakat funds. In addition, zakat management institutions can determine the productive distribution programs that are appropriate for the mustahik community in the village.

\section{LITERATURE REVIEW}

ZVI is a new index for the purpose of measuring the status of a village. Prior studies using ZVI analysis tools have been carried out by the BAZNAS Center of Strategic Studies (Puskas or Pusat Kajian Strategis) in three locations: Secanggang Village and Selontong Village in Langkat Regency, and Buring Village in Malang City. Nurzaman and Annisa (2017) stated that those three locations had index values that were categorized as "fairly good," with Secanggang Village at 0.51, Selontong Village at 0.53, and Buring at 0.59 . Since these three index values fall within the range $0.41-0.60$, the three locations can be considered for zakat fund assistance.

Studies looking at the classification of villages in Demak Regency and Sayung Subdistrict have also previously been carried out using the Village Development Index (IPD, or Indeks Pembangunan Desa) and Village Building Index (IDM or Indeks Desa Membangun). The IPD was developed by Bappenas and the Central Bureau of Statistics (BPS or Badan Pusat
Statistik) in 2014 and measures the level of village development based on five dimensions: services, infrastructure condition, accessibility/transportation, public services, and government administration. It has three different statuses for the purpose of classifying villages: independent, developing, and left behind. Demak Regency has an IPD value of 66.74, which means that villages in Demak Regency, based on the average, can be categorized as "developing."

The IDM was produced by the Ministry of Villages in 2015. It measures the level of village development based on the three dimensions of social, economic resilience, and ecology. The IDM has five statuses for the purpose of classifying villages: very underdeveloped, underdeveloped, developing, developed, and independent. Demak Regency has an IDM value of 0.6186 , which means that its villages can be categorized as "developing."

Ali et al., in their study entitled "The Comparative Study between Productive and Consumptive Based Zakat" in 2016, stated that the distribution of zakat in both a consumptive and productive manner is able to concurrently improve prosperity and reduce poverty among mustahik. However, productive zakat is more effective in reducing poverty than consumptive zakat since the distribution of productive zakat by amil to mustahik is always accompanied by business assistance that not only provides information on how to properly run a business, but also on how to practice religion in line with Islamic law. The religious education provided by an amil plays an important role in enhancing religious understanding and awareness among mustahik, in addition to playing an important role in lifting them out of spiritual poverty.

One of the indicators in the ZVI is the dimension of da'wah; indeed, aside from the aspect of material improvement, the spiritual aspect is very important 
(Puskas BAZNAS, 2017). This is consistent with the research of Beik and Arsyianti (2016) entitled "Measuring Zakat Impact on Poverty and Welfare using the CIBEST Model Method." The authors of that study stated that zakat management organizations must improve their programs of supervision in order to better anticipate the degradation of the spiritual conditions of mustahik. Specifically, evaluation based on knowledge assistance and spiritual conditions must be improved.

Wijaya (2010), in a study entitled Kemiskinan dan Pemberdayaan Masyarakat (Poverty and Community Empowerment), highlighted the tendency for empowerment-based poverty eradication in developing countries such as Indonesia. Community empowerment in the context of community development refers to the community gaining increased power and authority to act in order to overcome its own problems. The duty of the empowerment facilitator is to develop a learning process for local communities to build a level of independence in solving the problems that they face. Such independence then manifests itself in the increasing empowerment of social groups to fulfill the basic needs of their members.

The ZCD program is based on the empowerment of communities and village and aims to comprehensively integrate the dimensions of Da'wah, Economic, Education, Health, and Social Humanity, funded through zakat, infaq, alms, and other social religious funds. Based on the Zakat Community Development Guidelines (2017), there are four principles of the ZCD program: (1) trustworthy and responsible; sustainable; (3) participatory; and (4) integrated. The main objective of a ZCD program is the creation of a prosperous and independent society (2017 Zakat Community Development Guidelines). The ZCD program has the following outputs: (1) The realization of a community with morality (akhlaqul karimah); (2) The realization of strong and independent community institutions; (3) An increase in the rate of participation in compulsory education; (4) An increase in public knowledge about health and health status through the development of a clean and healthy lifestyle; (5) Increases in income and the existence of a sustainable community livelihood system; and (6) An increasing comprehension of disaster risk reduction among the community based on the local culture.

\section{RESEARCH METHODOLOGY}

\section{Data}

This research was conducted in Bedono Village in February 2018. Bedono is one of BAZNAS's targets for implementation of the ZVI. The data used in this research comprise primary and secondary data. The primary data were obtained through a process of interviews and focus group discussions (FGDs) with respondents, while the secondary data were obtained through BAZNAS Demak, BPS Demak, BPS Sayung, the administration data of Bedono Village, and a review of the literature based on research derived from journals, books, and other sources. Purposive sampling was employed as the sampling technique.

The participants in this study comprised the Head of Bedono Village and the five heads of RTs (hamlets) as the main respondents, with members of Bedono Village, local village officials, health cadres, State Electricity Company (PLN) officers, and Bedono Village religious figures as the supporting respondents. The eligibility criteria for the respondents in this study were interviewees with an in-depth understanding of the environmental conditions of villages considered to be vulnerable or critical based on the aspects of economic, health, education, social humanity, and da'wah. 
Both quantitative and qualitative approaches to data analysis were used in this study. The qualitative approach was employed for the purpose of identifying facts from the results of the literature studies and interviews, FGDs, and questionnaires obtained from the sources. The quantitative approach, meanwhile, was used to generate the components of the ZVI. The quantitative analysis uses the Multi-Stage Weighted Index as its calculation estimation technique in order to display data in the form of ZVI calculation results.

\section{Zakat Village Index (ZVI) Analysis}

ZVI is an instrument used to measure the condition of a village, in order to identify those villages that are eligible for assistance in the form of zakat funds. The ZVI can also be used as a tool for the monitoring and evaluation of the zakat management process in place in a village. The ZVI is organized based on processoriented principles that can be used by zakat management organizations to obtain a view of the program's ongoing progress. The objective is for the ZVI to be used as a reference for zakat management organizations in terms of creating certain village or community-based empowerment programs, implemented either presently or in the near future, to be more measurable and integral to the management. The purpose of ZVI is to measure the potential of a village or urban village and evaluate the village-based mustahik community that has been assisted by zakat funds.

ZVI takes the form of a composite index composed of a number of indices for each component. This format is determined using mixed methods-based research. Mixed methods is a type of research methodology that involves a combination of quantitative and qualitative methods. The qualitative method is used to develop the components of the National Zakat Index (NZI or Indeks Zakat Nasional), while the quantitative method is employed to construct the calculation estimation model.

ZVI comprises the five dimensions of Economic, Health, Education, Social Humanity, and Da'wah. Each dimension is reduced to 15 variables and 39 indicators, accompanied by their respective contribution weightings. The calculations for obtaining ZVI values are conducted using the Multi-Stage Weighted Index method. This method combines every weighted score for the constituent components of each index, with the aim of conducting a gradual and procedural weighting (measuring). Details of the ZVI components are presented in Table 1.

Table 1. Weighted scores of the ZVI components

\begin{tabular}{|c|c|c|c|c|c|}
\hline Dimension & $\begin{array}{c}\text { Weighted } \\
\text { score }\end{array}$ & Variable & $\begin{array}{l}\text { Weighted } \\
\text { score }\end{array}$ & Indicator & $\begin{array}{l}\text { Weighted } \\
\text { score }\end{array}$ \\
\hline \multirow{9}{*}{ Economic } & \multirow{9}{*}{0.25} & \multirow{3}{*}{$\begin{array}{l}\text { Productive } \\
\text { economic } \\
\text { activities }\end{array}$} & \multirow{3}{*}{0.28} & Number of superior products & 0.33 \\
\hline & & & & Labor force participation rate & 0.35 \\
\hline & & & & $\begin{array}{l}\text { Number of creative industry } \\
\text { activists }\end{array}$ & 0.32 \\
\hline & & \multirow{2}{*}{ Trade centers } & \multirow{2}{*}{0.24} & Market & 0.53 \\
\hline & & & & Trading center & 0.47 \\
\hline & & \multirow{3}{*}{$\begin{array}{c}\text { Access to } \\
\text { transportation \& } \\
\text { logistics / } \\
\text { shipping } \\
\text { services } \\
\end{array}$} & \multirow[b]{3}{*}{0.22} & Accessibility of village roads & 0.42 \\
\hline & & & & Modes of public transportation & 0.32 \\
\hline & & & & Logistics / shipping services & 0.26 \\
\hline & & $\begin{array}{l}\text { Access to } \\
\text { financial }\end{array}$ & 0.26 & $\begin{array}{l}\text { Availability and accessibility } \\
\text { of financial institutions }\end{array}$ & 0.37 \\
\hline
\end{tabular}




\begin{tabular}{|c|c|c|c|c|c|}
\hline & & institutions & & $\begin{array}{l}\text { Percentage of people in debt to } \\
\text { moneylenders }\end{array}$ & 0.29 \\
\hline & & & & $\begin{array}{l}\text { Percentage of people who use } \\
\text { financial services products }\end{array}$ & 0.34 \\
\hline \multirow{8}{*}{ Health } & \multirow{8}{*}{0.16} & \multirow{3}{*}{ Public health } & \multirow{3}{*}{0.41} & Clean water facilities & 0.37 \\
\hline & & & & $\begin{array}{l}\text { Number of houses with } \\
\text { bathrooms and toilets }\end{array}$ & 0.29 \\
\hline & & & & $\begin{array}{l}\text { Number of houses with access } \\
\text { to drinkable water }\end{array}$ & 0.34 \\
\hline & & \multirow{4}{*}{ Health services } & \multirow{4}{*}{0.36} & $\begin{array}{l}\text { Puskesmas (public health } \\
\text { center) facilities }\end{array}$ & 0.25 \\
\hline & & & & $\begin{array}{l}\text { Polindes (village } \\
\text { childbirth/maternity post) } \\
\text { facilities }\end{array}$ & 0.25 \\
\hline & & & & $\begin{array}{l}\text { Posyandu (child development } \\
\text { center) facilities }\end{array}$ & 0.25 \\
\hline & & & & Certified doctors & 0.25 \\
\hline & & $\begin{array}{l}\text { Health } \\
\text { insurance }\end{array}$ & 0.23 & - & 1.00 \\
\hline \multirow{5}{*}{ Education } & \multirow{5}{*}{0.20} & \multirow{2}{*}{$\begin{array}{c}\text { Level of } \\
\text { education and } \\
\text { literacy }\end{array}$} & \multirow[b]{2}{*}{0.50} & Level of the village population & 0.48 \\
\hline & & & & $\begin{array}{l}\text { Ability to read and count in } \\
\text { communities }\end{array}$ & 0.52 \\
\hline & & \multirow{3}{*}{$\begin{array}{l}\text { Educational } \\
\text { facilities }\end{array}$} & \multirow{3}{*}{0.50} & $\begin{array}{l}\text { Availability of learning } \\
\text { facilities and infrastructure }\end{array}$ & 0.34 \\
\hline & & & & Access to schools & 0.34 \\
\hline & & & & $\begin{array}{l}\text { Availability of qualified } \\
\text { teachers }\end{array}$ & 0.32 \\
\hline \multirow{7}{*}{$\begin{array}{l}\text { Social } \\
\text { Humanity }\end{array}$} & \multirow{7}{*}{0.17} & \multirow{2}{*}{$\begin{array}{l}\text { Open public } \\
\text { interaction } \\
\text { space facilities }\end{array}$} & \multirow{2}{*}{0.36} & Availability of sports facilities & 0.44 \\
\hline & & & & Community activity groups & 0.56 \\
\hline & & \multirow{4}{*}{$\begin{array}{l}\text { Electricity, } \\
\text { communication, } \\
\& \text { information } \\
\text { infrastructure }\end{array}$} & \multirow{4}{*}{0.43} & Availability of electricity & 0.32 \\
\hline & & & & $\begin{array}{l}\text { Access to communication } \\
\text { (handphone) }\end{array}$ & 0.25 \\
\hline & & & & Internet access & 0.23 \\
\hline & & & & $\mathrm{TV} /$ radio broadcasts & 0.20 \\
\hline & & $\begin{array}{c}\text { Mitigation of } \\
\text { natural disasters }\end{array}$ & 0.21 & - & 1.00 \\
\hline \multirow{8}{*}{ Da'wah } & \multirow{8}{*}{0.22} & \multirow{3}{*}{$\begin{array}{l}\text { Religious } \\
\text { facilities and } \\
\text { companions }\end{array}$} & \multirow{3}{*}{0.33} & Availability of mosques & 0.31 \\
\hline & & & & Access to mosques & 0.32 \\
\hline & & & & Religious companions & 0.37 \\
\hline & & \multirow{2}{*}{$\begin{array}{c}\text { Rate of } \\
\text { religious } \\
\text { knowledge of } \\
\text { the community }\end{array}$} & \multirow{2}{*}{0.30} & $\begin{array}{l}\text { Level of Qur'an literacy of the } \\
\text { community }\end{array}$ & 0.46 \\
\hline & & & & $\begin{array}{l}\text { Indicators of public awareness } \\
\text { of zakat and infaq }\end{array}$ & 0.54 \\
\hline & & \multirow{3}{*}{$\begin{array}{c}\text { Rate of } \\
\text { religious } \\
\text { activity and } \\
\text { community } \\
\text { participation }\end{array}$} & \multirow{3}{*}{0.37} & Routine religious activities & 0.30 \\
\hline & & & & $\begin{array}{l}\text { Participation in five-times- } \\
\text { daily prayer activity }\end{array}$ & 0.39 \\
\hline & & & & $\begin{array}{l}\text { Participation in religious } \\
\text { routine activities }\end{array}$ & 0.31 \\
\hline
\end{tabular}

Source: BAZNAS Center of Strategic Studies (2017)

The ZVI formulation model was systematically divided into five steps. The first step involved the creation of a 1-5 Likert scale, with a score of 1 representing 
the worst condition, and a score of 5 representing an excellent condition. The second step was the measurement of every variable against the index. The formulation of this step is provided below:

Where,

$$
I_{i}=\frac{\left(S_{i}-S_{\min }\right)}{\left(S_{\max }-S_{\min }\right)}
$$

$\mathrm{I}_{\mathrm{i}} \quad$ : Value of indicator $\mathrm{i}$

$\mathrm{S}_{\mathrm{i}} \quad$ : Actual score of indicator $\mathrm{i}$

$\mathrm{S}_{\max }:$ Maximum score (5)

$\mathrm{S}_{\min }:$ Minimum score (1)

In the third step, the values obtained for each of the indicators were multiplied by their respective weights to derive the index for that indicator. The fourth step involved multiplying the values obtained for each indicator by their respective weights to derive the index for each variable. The final step was to multiply the index obtained for each variable by its respective weight in order to obtain an index score for every dimension. The results were in the form of the ZVI composite index, as follows:

$$
\begin{gathered}
\mathrm{ZVI}=0.25 \mathrm{X}_{1}+0.16 \mathrm{X}_{2}+0.20 \mathrm{X}_{3}+ \\
0.17 \mathrm{X}_{4}+0.22 \mathrm{X}_{5}
\end{gathered}
$$

Where,

$\begin{array}{lll}\mathrm{ZVI} & : \text { Zakat Village Index } \\ \mathrm{X}_{1} & : \text { Economic dimension } \\ \mathrm{X}_{2} & : \text { Health dimension } \\ \mathrm{X}_{3} & : \text { Education dimension } \\ \mathrm{X}_{4} & : \text { Social Humanity dimension } \\ \mathrm{X}_{5} & : \text { Da'wah dimension }\end{array}$

The index generated scores in the range $0.00-1.00$. The ZVI valuation scale was then used to organize the rural conditions into the following five classifications:

1. (0.00-0.20) "not good" and highly prioritized for assistance by zakat funds.

2. (0.21-0.40) "less good" and prioritized for assistance by zakat funds.
3. (0.41-0.60) "fairly good" and considered for assistance by zakat funds.

4. (0.61-0.80) "good" and less prioritized for assistance by zakat funds.

5. (0.81-1.00) "very good" and not prioritized for assistance by zakat funds.

\section{RESULTS AND DISCUSSION}

ZVI measurements were taken across the five dimensions of Economic, Health, Education, Social Humanity, and Spiritual (da'wah). In the Economic dimension, Bedono Village has an index value of 0.18 and is classified in the "not good" category. The Economic dimension has the lowest score out of all the dimensions in the ZVI. This dimension consists of four variables: productive economic activities, trade centers, access to transportation and logistics / shipping services, and access to financial institutions.

The variable of productive economic activities consists of three indicators: number of superior products, labor force participation rate, and number of creative industry activists. Meanwhile, the main trade centers variable consists of two indicators: market and trading center. The variable access to transportation and logistics services / shipping consists of three indicators: accessibility of village roads, modes of public transportation, and logistics / shipping services. The fourth variable of the Economic dimension is access to financial institutions and is made up of three indicators: availability and accessibility of financial institutions, percentage of people in debt to moneylenders, and the percentage of people who use financial services products.

Bedono Village does not have any superior products, which means the index score for this indicator is 0. Even so, Bedono Village does have some economic potential that can be developed, in the 
form of the fisheries and tourism sectors. The fisheries sector in Bedono Village includes the cultivation of milkfish, mullet fish, tilapia fish, white shrimp, mangrove crabs, and blood clams. The yield derived from milkfish cultivation in Bedono Village reached 1.5 tons per year (Widiyanto, 2013). Meanwhile, the cultivation of blood clams remains in a trial phase with the formation of a group of residents focused on cultivating blood clams in Bedono Village.

The economic potential of the tourism sector comprises the mangrove forest and religious tourism destinations in the form of the ancestral graves of K.H. Abdulloh Mudzakir. The area of Bedono's mangrove ecosystem saw extensive changes during the period 2004-2009, increasing in size from 22.41 ha to 43.03 ha (Chafid et al., 2012). The economic value of the mangrove ecosystem stands at 2,037,005,895 rupiahs / year (Widiyanto, 2013).

K.H. Abdulloh Mudzakir's ancestral graves are located in the Java Sea, with access via a wooden bridge connected to Tambaksari hamlet, leading to its naming by locals as a floating tomb. Based on the interviews with informants, there has been a continual increase in tourists as pilgrims arriving to visit the floating tomb. The visitor numbers usually peak every Friday night and then every day during the month of Ramadan.

The labor force participation rate indicator had an index score of 0.5. Bedono Village has a labor force participation rate of 58.07 percent based on a population of 2,611 people of productive age (15-64 years old). The majority of people in the Bedono Village community are laborers, consisting of farm workers (21.46 percent), construction workers (17.19 percent), and industrial workers (15.92 percent). Fishing is also a dominant profession in Bedono Village, with fishermen accounting for 19.30 percent of the workforce. These three indicators can be combined to give a score for the productive economic activities variable of 0.26 , thus indicating that the productive economic activities in Bedono Village fall within the "less good" category.

For the trading center variable, the market and trading center indicators have index scores of 0 and 0.25 , respectively. This is due to the unavailability of markets in rural areas, including both permanent and semi-permanent markets (seasonal markets). Many sale and purchase transactions are held at Sayung Market, \pm $6 \mathrm{~km}$ from the center of the village. Difficult transportation access is one factor that contributes to the difficult availability of goods in Bedono Village. Economic activities continue to be held traditionally and have to fully utilize technology or online marketing. Based on the interviews with informants, there are approximately 31 small shops (warung in Indonesia) for the provision of daily goods, while minimarkets and stores are yet to become available in the village areas. When these two indicators are combined, the trade centers variable has a score of 0.12 . This means that trade centers for Bedono Village sits within the "not good" category.

On the other hand, the access to transportation and logistics services / delivery variable has an index score of 0.25 . The tidal flooding that has occurred continuously from 1980 has damaged the village road, resulting in a very low level of accessibility to the village of Bedono. Indeed, some parts of Bedono Village have been submerged by tidal floods. The hamlets of Tambaksari and Rejosari Senik have also been affected by tidal flooding and erosion, eventually leading to them becoming cut off by the sea. Roads and bridges have been damaged, meaning that transportation is mostly via the sea. Meanwhile, the remaining land routes are in a poor and damaged state, in addition to becoming submerged almost every afternoon or during high tide. At high tide or when there is rain, roads and bridges 
can become submerged in water up to 20$30 \mathrm{~cm}$ deep. Most land routes are impassible by even four-wheel-drive vehicles throughout the year. This lack of transportation access has resulted in the two hamlets of Bedono and Mondoliko becoming cut off from the center of the village. The only access to Bedono and Mondoliko is via the sea or through other villages, notably Sidogemah Village that has access via damaged roads. Meanwhile, the modes of public transportation and logistics / shipping service indicators have an index score of 0 , as Bedono Village has no public transportation routes or logistics services/delivery of goods. When these three indicators are combined, the access to transportation and logistics / shipping services variable is in the "not good" category, with an index score of 0.11 . This variable therefore has the lowest score of any indicator in the Economic dimension and ZVI.

Bedono Village has no financial institutions, either conventional or sharia, thus generating an index score for this indicator of 0 . The indicator percentage of people using financial services products also has an index score of 0 , based on the fact that only 8 percent of the population, or about 300 out of 3,740 residents, use financial products / services. For the indicator percentage of people in debt to moneylenders, the index score is 0.75 , as only 1.87 percent of people hold debts to moneylenders. When these three indicators are combined, the access to financial institutions variable has an index score of 0.22 and is classified as being in the "less good" category. Details of the index scores for the Economic dimension can be seen in Table 2.

Table 2. Economic dimension index scores

\begin{tabular}{|l|l|c|}
\hline No & \multicolumn{1}{|c|}{ Variables } & Index Score \\
\hline 1 & Productive economic activities $\left(\mathrm{X}_{11}\right)$ & 0.26 \\
\hline 2 & Trade centers $\left(\mathrm{X}_{12}\right)$ & 0.12 \\
\hline 3 & Access to transportation and logistics / shipping services $\left(\mathrm{X}_{13}\right)$ & 0.11 \\
\hline 4 & Access to financial services $\left(\mathrm{X}_{14}\right)$ & 0.22 \\
\hline Economic dimension index scores: & \\
$\mathrm{X}_{1}=0.28 \mathrm{X}_{11}+0.24 \mathrm{X}_{12}+0.22 \mathrm{X}_{13}+0.26 \mathrm{X}_{14}$ & \\
$\mathrm{X}_{1}=0.28(0.26)+0.24(0.12)+0.22(0.11)+0.26(0.22)$ & \\
$\mathrm{X}_{1}=0.18$ & \\
\hline
\end{tabular}

Source: Primary data (2018)

The second dimension of the ZVI is Health, comprising the three variables of public health, health services, and health insurance. Public health is divided into the three indicators of clean water facilities, number of houses with bathrooms and toilets, and number of houses with access to drinkable water. Meanwhile, the health services indicator consists of four indicators: Puskesmas (public health center) facilities, polindes (village childbirth post) facilities, posyandu facilities, and certified doctors.

The public health indicator has an index score of 0.66 , meaning that the health condition of the village of Bedono is classified as "good." Based on the administration data of Bedono (2018), the village contains a total of 1,246 houses. The condition of the villagers' houses in Bedono on average is habitable, with permanent roofs, walls, and floors made of wood or concrete. However, the majority of Bedono villagers' houses are in a poor state of repair due to being permanently flooded with seawater measuring a depth of $20-30 \mathrm{~cm}$ every day. The natural condition of Bedono Village means that the villagers are compelled to continuously carry out repairs to their houses. According to the Bedono Village Chief, houses built on stilts are the best type to 
withstand the natural conditions in the village. However, most of the villagers do not possess the financial means to embark on a remodeling of their houses to stand on stilts, or even to carry out the necessary repairs. As a result of these economic factors, many villagers are forced to remain in their homes in spite of their damaged state.

Meanwhile, clean water facilities cover all of the villagers' houses in Bedono Village. Drinkable water can also be accessed at 80 percent of the villagers' houses. The clean water used by the village community is PAM (water utility company) water. Despite this, however, out of 1,246 houses, only 10 percent have interior bathrooms and toilets, with the majority of these facilities located 10 meters from each house.

For the health services variable, the Bedono Village health service has an index score of 0.31 , meaning that the Bedono Village health services are in the "less good" category. There are several factors contributing to this, including the unavailability of puskesmas (public health centers) in the village area. The nearest health service that can be accessed is \pm 8 $\mathrm{km}$ from the center of the village, in the center of Sayung Subdistrict and the center of Demak Regency. This makes access to health services somewhat difficult for the village community. On the other hand, there are polindes facilities available in the village area, and these can be easily accessed by villagers, being located less than $2 \mathrm{~km}$ from the village center. Every two weeks, the polindes move from one village to another. With this system, every village, especially those that are isolated, maintains its access to midwives. Meanwhile, the availability of posyandu in the village area is considered to be good. Four out of five villages have active posyandu programs.

The health insurance variable is in the "not good" category, with an index score of 0. Only 7.22 percent of the Bedono Village community have health insurance. The low rate of community participation in health insurance is partly due to the poor access to financial institutions.

Overall, the health dimension has an index value of 0.38 . This shows that the health condition in Bedono is classified as "less good" and prioritized for assistance by zakat funds. The details of the Health dimension index scores are presented in Table 3.

Table 3. Health dimension index scores

\begin{tabular}{|l|l|c|}
\hline No & \multicolumn{1}{|c|}{ Variables } & Index Score \\
\hline 1 & Public health $\left(\mathrm{X}_{21}\right)$ & 0.66 \\
\hline 2 & Health services $\left(\mathrm{X}_{22}\right)$ & 0.31 \\
\hline 3 & Health insurance $\left(\mathrm{X}_{23}\right)$ & 0 \\
\hline Health dimension index scores: & \\
$\mathrm{X}_{2}=0.41 \mathrm{X}_{21}+0.36 \mathrm{X}_{22}+0.23 \mathrm{X}_{23}$ & \\
$\mathrm{X}_{2}=0.41(0.66)+0.36(0.31)+0.23(0.00)$ & \\
$\mathrm{X}_{2}=0.38$ & \\
\hline
\end{tabular}

Source: Primary data (2018)

The Education dimension consists of two variables: level of education and literacy, and educational facilities. The level of education and literacy variable comprises the indicators of the village population, and the ability to read and count in communities. In 2016, the percentage of Bedono villagers with a min. age of 10 years who had upper secondary school as their minimum education background stood at only 21.33 percent of the total population (BPS 2017), which resulted in an index score of 0.25 . Most people have graduated from lower 
secondary school, with a total of 830 people, followed by 863 upper secondary school graduates, 569 elementary school graduates, and 31 academy / college graduates. Meanwhile, the ability of the communities to read and count has an indicator of 0.5 , reflecting the fact that 71.43 percent of the Bedono Village population aged 15-45 years can read and count (BPS, 2017). When these two indicators are combined, the level of education and literacy variable is in the "less good" category, with a score of 0.38 .

The other variable for the Education dimension is educational facilities, which consists of the following three indicators: the availability of learning facilities and infrastructure, access to schools, and the availability of qualified teachers. The educational facilities variable has an index score of 1 and is in the "very good" category. There are three elementary schools in Bedono Village: SDN Bedono I, SDN Bedono II, and SDN Bedono III in Morosari, Pandansari, and Tonosari, with an average of 17 students per class. The three elementary schools have classrooms, desks, a chair for each student, and blackboards, all in good condition. There are 10 teachers, meaning the availability of teachers is also fulfilled. Despite this, however, the supporting facilities, such as fields for sports and ceremonies, are not suitable for use. The fields are always muddy and slippery due to the impact of the high tides and sea water that cover them on a daily basis.

The closest schools for residents to access are relatively short distances away: $\pm 1 \mathrm{~km}$ for the elementary school, and \pm 8 for the middle and high schools. However, at certain times, such as when the tide and floods occur, access to schools becomes difficult. Supporting facilities such as public transportation are also not yet available. When these two variables are combined, the education dimension is in the "good" category, with an index score of 0.69 , and is deemed to be less of a priority for assistance by zakat funds. The details of the index scores for the Education dimension are presented in Table 4.

Table 4. Education dimension index scores

\begin{tabular}{|l|l|c|}
\hline No & \multicolumn{1}{|c|}{ Variables } & Index Score \\
\hline 1 & Level of education and literacy $\left(\mathrm{X}_{31}\right)$ & 0.38 \\
\hline 2 & Educational facilities $\left(\mathrm{X}_{32}\right)$ & 1 \\
\hline Education dimension index scores: & \\
$\mathrm{X}_{3}=0.50 \mathrm{X}_{31}+0.50 \mathrm{X}_{32}$ & \\
$\mathrm{X}_{3}=0.50(0.38)+0.50(1.00)$ & \\
$\mathrm{X}_{3}=0.69$ & \\
\hline
\end{tabular}

Source: Primary data (2018)

The Social Humanity dimension has an index score of 0.48 and is classified in the "fairly good" category and considered for assistance by zakat funds. This dimension comprises the three variables of open public interaction space facilities; electricity, communication, and information infrastructure; and mitigation of disasters. The open public interaction space facilities variable has the two indicators of availability of sports facilities, and community activity groups.
In Bedono Village, there are no sports facilities, thus giving an index score for this indicator of 0 . The village formerly had five sports facilities; however, the fields became submerged by sea water and could no longer be used. The community activity groups indicator has an index score of 0.75 , which reflects the following five types of community activity groups that are active in Bedono Village: mangrove activists, PAMSIMAS (water supply and sanitation for low income 
communities), fishermen, and shellfish cultivation. When these two indicators are combined, the open public interaction space facilities variable has a score of 0.42 and falls within the "fairly good" category.

Meanwhile, the variable of electricity, communication, and information infrastructure consists of four indicators: the availability of electricity, access to communication, Internet access, and TV/radio broadcasts. The availability of electricity and TV/radio broadcasts indicators have an index score of 1 , reflecting that all villagers have access to electricity as well as to $\mathrm{TV}$ and radio broadcasts. However, the access to communication and Internet access indicators have an index score of 0.5, which is due to the very poor access to communication in Bedono Village. The telecommunication signal in the village area registers a signal strength of only 1-2 bars. Meanwhile, only 35 percent of the population has Internet access, with this predominantly being via villagers' cellphones. When these four indicators are combined, the electricity, communication, and information infrastructure variable has a score of 0.76 and is classified in the "good" category.

On the other hand, however, Bedono Village does not have a disaster prevention system. Therefore, the mitigation of natural disasters variable has an index score of 0 . Details of the scores for the Social Humanity dimension are given in Table 5.

Table 5. Social Humanity dimension index scores

\begin{tabular}{|l|l|c|}
\hline No & \multicolumn{1}{|c|}{ Variables } & Index Score \\
\hline 1 & Open public interaction space facilities $\left(\mathrm{X}_{41}\right)$ & 0.42 \\
\hline 2 & Electricity, communication, and information infrastructure $\left(\mathrm{X}_{42}\right)$ & 0.76 \\
\hline 3 & Mitigation of natural disasters $\left(\mathrm{X}_{43}\right)$ & 0 \\
\hline Social Humanity dimension index scores & \\
$\mathrm{X}_{4}=0.36 \mathrm{X}_{41}+0.43 \mathrm{X}_{42}+0.21 \mathrm{X}_{43}$ & \\
$\mathrm{X}_{4}=0.36(0.42)+0.43(0.76)+0.21(0.00)$ & \\
$\mathrm{X}_{4}=0.48$ & \\
\hline
\end{tabular}

Source: Primary data (2018)

The final dimension of the ZVI is Da'wah. This dimension has an index score of 0.75 , thus indicating that the spiritualism activities in Bedono Village fall in the "good" category and are less prioritized for assistance by zakat funds. The Da'wah dimension has three variables: religious facilities and companions, the rate of religious knowledge of the community, and the rate of religious activity and community participation.

The facilities and religious companions variable comprises the three indicators of availability of mosques, access to mosques, and religious companions. This variable has an index score of 0.765 , which places it in the "good" category. Bedono Village has four mosques and 17 musola (small mosques), all in a fairly decent condition, which gives an index score for this indicator of 0.5 . Meanwhile, access to mosques has an index score of 0.75 , due to the fact that the nearest mosque and musola are less than 500 meters away, along a predominantly soil/stone road.

The religious companions indicator has an index score of 1 . This is due to the number of religious companions assigned to teach religion and recite the Quran in Bedono Village reaching \pm 40 persons.

The rate of religious knowledge of the community variable consists of the two indicators of level of Qur'an literacy of the community indicator, and indicators of public awareness of zakat and infaq. This variable has an index score of 1 and is classified as being in the "very good" 
category. The entire population of Bedono Village is made up of Muslims who are able to read Al-Quran and fulfill the obligation of zakat fitrah in the month of Ramadan. However, Bedono Village does not have a zakat management institution, and zakat collection has not been properly recorded. Zakat distribution is either performed traditionally or is not conducted through the institution, meaning it is given to the mustahik directly, in this case by the people acting as religious teachers/ companions.

The rate of religious activity and community participation variable has an index score of 0.53 , which places it in the "good" category. This variable contains the three indicators of routine religious activities, participation in five-times-daily prayer, and participation in religious routine activities. The religious routine activities indicator has an index score of 1 , reflecting the fact that routine religious activities are held once a week every week. Since only 10 percent of the people who perform Friday prayers also engage in daily prayers, this gives an index score of 0 for the participation in five-times-daily prayer indicator. The participation in religious routine activities indicator, meanwhile, has an index score of 0.75 , since 60 percent of the Muslim community attend and participate in every religious activity held in the village. Details of the Da'wah dimension scores are given in Table 6.

Table 6. Da'wah dimension index scores

\begin{tabular}{|c|l|c|}
\hline No & \multicolumn{1}{|c|}{ Variables } & Index Score \\
\hline 1 & Religious facilities and companions $\left(\mathrm{X}_{51}\right)$ & 0.765 \\
\hline 2 & Rate of religious knowledge of the community $\left(\mathrm{X}_{52}\right)$ & 1 \\
\hline 3 & Rate of religious activity and community participation $\left(\mathrm{X}_{53}\right)$ & 0.53 \\
\hline \multicolumn{2}{|c|}{$\mathrm{Da}^{\prime} \mathrm{wah} /$ spiritual dimension index scores } & \\
$\mathrm{X}_{5}=0.33 \mathrm{X}_{51}+0.30 \mathrm{X}_{52}+0.37 \mathrm{X}_{53}$ & \\
$\mathrm{X}_{5}=0.33(0.765)+0.30(1.00)+0.37(0.53)$ & \\
$\mathrm{X}_{5}=0.75$ & \\
\hline
\end{tabular}

Source: Primary data (2018)

Based on the calculation of the index scores for the Economic, Health, Education, Social Humanity, and Da'wah dimensions, the overall ZVI value for Bedono Village is found to be 0.49 . This means that Bedono Village is categorized as "fairly good" and can be considered for assistance by zakat funds. Details of the ZVI results are shown in Table 7.

Table 7. Zakat Village Index (ZVI) in Bedono Village

\begin{tabular}{|l|c|c|c|}
\hline \multicolumn{1}{|c|}{ Dimension } & $\begin{array}{c}\text { Index } \\
\text { Score }\end{array}$ & Information & Interpretation \\
\hline Economic $\left(\mathrm{X}_{1}\right)$ & 0.18 & Not good & Highly prioritized for assistance by zakat funds \\
\hline Health $\left(\mathrm{X}_{2}\right)$ & 0.38 & Less good & Prioritized for assistance by zakat funds \\
\hline Education $\left(\mathrm{X}_{3}\right)$ & 0.69 & Good & Less prioritized for assistance by zakat funds \\
\hline Social Humanity $\left(\mathrm{X}_{4}\right)$ & 0.48 & Fairly good & Considered for assistance by zakat funds \\
\hline Da'wah $\left(\mathrm{X}_{5}\right)$ & 0.75 & Good & Less prioritized for assistance by zakat funds \\
\hline ZVI scores in Bedono Village \\
ZVI $=0.25 \mathrm{X}_{1}+0.16 \mathrm{X}_{2}+0.20 \mathrm{X}_{3}+0.17 \mathrm{X}_{4}+0.22 \mathrm{X}_{5}$ \\
$\mathrm{ZVI}=0.25(0.18)+0.16(0.38)+0.20(0.69)+0.17(0.48)+0.22(0.75)$ \\
$\mathrm{ZVI}=0.4904 \sim 0.49$
\end{tabular}

Source: Primary data (2018) 


\section{CONCLUSION AND} RECOMMENDATIONS

The results of the ZVI calculation show that Bedono Village falls within the "fairly good" category, with an index value of 0.49 , and is thus categorized as considered for assistance by zakat funds. The lowest index scores are for the Economic (0.18), Health (0.38), and Social Humanity (0.49) dimensions, while the Education and Da'wah dimensions have index scores of 0.69 and 0.75 respectively.

Some of the measures that may be taken to improve the ZVI of Bedono Village are: (1) improve transportation accessibility; (2) initiate a ZCD program based on economic development, such as the opening of a floating market and maximizing the maritime and tourism sectors to support the market in Bedono; and (3) launch a floating house program to minimize the impact of tidal flooding in Bedono.

\section{REFERENCES}

Ali, K. M., Amalia, N. N., \& El Ayyubi, S. (2016). The comparative study between productive and consumptive based zakat. Jurnal Al-Muzara'ah, 4(1).

Beik, I. S., \& Arsyianti, L. D. (2016). Measuring zakat impact on poverty and welfare using CIBEST model. Journal of Islamic Monetary Economics and Finance, 1(2).

[BPS] Badan Pusat Statistik Kabupaten Demak (2017). Kabupaten Demak dalam Angka 2017.

[BPS] Badan Pusat Statistik Kecamatan Sayung (2017). Kecamatan Sayung dalam Angka 2017.

Chafid, M. A., Pribadi, R., \& Suryoputro Dwi, A. A. (2012). Kajian perubahan luas lahan mangrove di Desa Bedono Kecamatan Sayung Kabupaten Demak menggunakan Citra Satelit Ikonos tahun 2004 dan
2009. Journal of Marine Research, 1, 167-173.

Damaywanti, K. (2013). Dampak Abrasi Pantai terhadap Lingkungan Sosial (Studi Kasus di Desa Bedono, Sayung Demak). Prosiding Seminar Nasional Pengelolaan Sumberdaya Alam dan Lingkungan 2013. Bandung: Puslitbangkim.

Direktorat Koordinasi Pendistribusian, Pendayagunaan, Renbang dan Diklat Zakat Nasional. 2017. Pedoman Zakat Community Development. Jakarta (ID): Badan Amil Zakat Nasional.

Indeks Desa Membangun 2015. Kementrian Desa, Pembangunan Daerah Tertinggal, dan Transmigrasi. Jakarta.

[KPPD; BPS] Kementrian Perencanaan Pembangunan Nasional / Badan Perencanaan Pembangunan Nasional; Badan Pusat Statistik. Indeks Pembangunan Desa: Tantangan Pemenuhan Standar Pelayanan Minimum Desa. Jakarta (ID).

Nurzaman, M. S, \& Annisa, N. (2017). Implementasi IDZ dalam Program ZCD BAZNAS. Jurnal Ekonomi Islam Republika.

Panitia RAKERNAS BAZNAS. 2018. Laporan Pengelolaan Zakat Kabupaten Demak 2016-2017. Jakarta (ID).

[PUSKAS] Pusat Kajian Strategi Badan Amil Zakat Nasional. 2017. Indeks Desa Zakat.

Widiyanto, A., Saputra, S. W., \& Purwanti, F. (2013). Valuasi ekonomi pemanfaatan ekosistem mangrove di Desa Bedono, Demak. Journal of Management of Aquatic Resources, 2(3), 138-142.

Wijaya, M. (2010). Kemiskinan dan pemberdayaan masyarakat desa. Journal of Rural and Development, l(1). 
Farikhatusholikhah

Bogor Agricultural University Indonesia

farikha9717@gmail.com

Tanti Novianti

Bogor Agricultural University Indonesia

Khalifah Muhamad Ali

Bogor Agricultural University Indonesia 